\title{
Prior Medication Usage
}

National Cancer Institute

\section{Source}

National Cancer Institute. Prior Medication Usage. NCI Thesaurus. Code C82522.

An indication or description that medications were taken previously. 